\title{
Phytochemical screening, antimycobacterial activity and acute toxicity of crude extracts of selected medicinal plant species used locally in the treatment of tuberculosis in Uganda
}

\author{
Benson Oloya ${ }^{1,2^{*}} \mathbb{0}$, Jane Namukobe ${ }^{1}$, Willy Ssengooba ${ }^{3}$, Mathias Afayoa $^{4}$ and Robert Byamukama ${ }^{1}$
}

\begin{abstract}
Background: Tuberculosis (TB) is one of the leading causes of death globally, and the rise in drug-resistant forms of TB has become a significant threat. Subsequently, it is crucial to explore new, effective and safe anti-TB agents. This study aimed at conducting phytochemical screening, antimycobacterial activity, and acute toxicity of the selected plant species' crude extracts to assess their toxicological potentials and efficacies against TB.

Methods: The aqueous and methanol/dichloromethane (DCM) (1:1) extracts of each selected plant species were subjected to phytochemical screening and antimycobacterial activity using microplate alamar blue assay. For acute toxicity, a single dose $(2000 \mathrm{mg} / \mathrm{kg}$ ) of the aqueous extracts was orally administered to each animal following the Organization for Economic Cooperation and Development (OECD) guidelines No. 425 and then observed for 14 days. The animals were closely observed on the general behavior and clinical signs of toxicity, and body weights were recorded. After the termination of the experiment, hematological, biochemical, and histopathological analyses were performed.

Results: The extracts contained alkaloids, flavonoids, tannins, saponins, steroids, terpenoids, resins, cardiac glycosides, phenolic compounds, and coumarins. Aqueous extracts showed moderate to weak activity against the susceptible $\left(\mathrm{H}_{37} \mathrm{Rv}\right) \mathrm{M}$. tuberculosis strain and weak activity against the MDR-TB strain with Minimum Inhibitory Concentrations (MIC $\mu \mathrm{g} / \mathrm{mL}$ ) ranging from 293.0-2344.0 and 1172.0-4688.0, respectively. Methanol/DCM extracts showed significant to moderate activity against the susceptible TB strain and moderate to weak activity against the MDR-TB strain with MIC $(\mu \mathrm{g} / \mathrm{mL})$ ranging from 98.0-586.0 and 293.0-781.0, respectively. One mortality was recorded from the A. coriaria treated group following the acute toxicity tests, but the $\mathrm{LD}_{50}$ of all the extracts was estimated to be above $2000 \mathrm{mg} /$ $\mathrm{kg}$. Histopathological analyses did not show any significant lesions in the examined organs except those from the $A$. coriaria treated group.

Conclusion: Phytochemical screening of the extracts revealed the presence of alkaloids, tannins, saponins, flavonoids, steroids, terpenoids, resins, cardiac glycosides, phenolic compounds, and coumarins. All the methanol/DCM extracts of the plant species studied have promising antimycobacterial activity. The selected plant extracts studied exhibited low acute toxicity levels except for A. coriaria and could be safe for formulations into herbal products.
\end{abstract}

*Correspondence: b.oloya@muni.ac.ug

${ }^{1}$ Department of Chemistry, College of Natural Sciences, Makerere University, P.O. Box 7062, Kampala, Uganda

Full list of author information is available at the end of the article permits use, sharing, adaptation, distribution and reproduction in any medium or format, as long as you give appropriate credit to the original author(s) and the source, provide a link to the Creative Commons licence, and indicate if changes were made. The images or other third party material in this article are included in the article's Creative Commons licence, unless indicated otherwise in a credit line to the material. If material is not included in the article's Creative Commons licence and your intended use is not permitted by statutory regulation or exceeds the permitted use, you will need to obtain permission directly from the copyright holder. To view a copy of this licence, visit http://creativecommons.org/licenses/by/4.0/. 
Keywords: Phytochemistry, Antimycobacterial activity, Acute toxicity, Tuberculosis, Medicinal plants

\section{Background}

Tuberculosis (TB) has been ranked among the top causes of death worldwide and the leading cause of death emanating from a single infectious agent, and since 2007, ranks above HIV/AIDS [1]. The emergence of drugresistant TB has exacerbated this problem. There is a need for multifaceted interventions to reverse this trend. One viable option is exploring more effective treatments derived from medicinal plants because from the earliest days of humanity, they have been the foundation of health care globally. In addition, medicinal plants have contributed to modern drug discovery and are still being used widely with significant importance in international trade $[2,3]$. About $90 \%$ of the population in some countries in Africa still depend exclusively on medicinal plant products as sources of medicines [4].

Furthermore, scientific attention to medicinal plants has significantly increased recently. This resurgence mainly arises due to the increased efficacy of novel drugs of plant origin, growing fears about the after-effects of contemporary medicine, and the emergence of resistance to existing drugs. Therefore, it is indispensable to search for novel molecular structures as templates for drug development from plants [5]. From history, the most outstanding sources of new anti-TB drugs have been natural products, although there are other potential sources, such as synthetic and combinatorial chemistry [6]. Moreover, some studies have shown that plants have antimycobacterial activity and contain antimycobacterial compounds [7-10]. From ethnopharmacological surveys, the leaves, stem, or root barks of the following medicinal plant species, selected for investigation in this study, have been used to manage TB by the local people in Uganda: Acacia hockii, Albizia coriaria, Combretum molle, Warburgia ugandensis, and Zanthoxylum leprieurii [11-15].

Medicinal plants often possess various phytoconstituents, many of them with unidentified biological properties, which could be toxic and cause drug interactions that are harmful to human health [16]. Consequently, assessment of the toxicity of a substance is critical when considering it for use as a drug since exposure to toxic substances is dangerous to both humans and animals [17]. Besides, there is limited documentation on the safety profile of plant-derived medicines, which does not satisfy the regulatory criteria of the category of drugs. It is necessary to undertake systematic studies of natural products and their phytoconstituents regarding their effectiveness and safety before using them as botanical drugs $[18,19]$.

This study focused on analyzing the methanol/DCM $(1: 1, \mathrm{v} / \mathrm{v})$ and aqueous crude extracts of the selected plant species to assess their toxicological potentials and efficacies against $M$. tuberculosis.

\section{Materials and methods \\ Selection criteria}

The medicinal plant species considered in the present study were selected based on their high frequency of mention registered from three or more different ethnobotanical surveys reported in the literature for the treatment of TB. In addition, they had no reports of similar studies using the solvent systems employed in the present study.

\section{Plant material}

Plant parts from Acacia hockii De Wild. (Fabaceae), Albizia coriaria Oliv. (Fabaceae), and Combretum molle R.Br. ex G.Don (Combretaceae) were collected from Zombo district, Uganda, while the stem bark of Warburgia ugandensis Sprague (Canellaceae) was harvested from Mabira Forest in Buikwe district, Uganda, and the root bark of Zanthoxylum leprieurii Guill. \& Perr. (Rutaceae) was from Mpanga Forest Reserve in Mpigi district, Uganda, in November 2020. Botanical identification was done by a taxonomist from Makerere University Herbarium and voucher specimen Nos.: O.B. 15, Accession No. 50967 (Zanthoxylum leprieurii); O.B. 16, Accession No. 50999 (Warburgia ugandensis Sprague); O.B. 17, Accession No. 51000 (Combretum molle); O.B. 18, Accession No. 51001 (Acacia hockii); O.B. 19, Accession No. 51002 (Albizia coriaria) were deposited at Makerere University Herbarium. The plant parts were air-dried at room temperature for at least 3 weeks and then pounded into fine powder.

\section{Extraction process}

For organic extractions, the powdered plant part (60 g) of each of the following: A. hockii (stem bark), A. coriaria (stem bark), C. molle (leaves), W. ugandensis (stem bark), and Z. leprieurii (root bark) was soaked in a mixture of methanol/DCM $(1: 1, \mathrm{v} / \mathrm{v})(400 \mathrm{~mL})$ for $24 \mathrm{~h}$, with occasional shaking. The extracts were filtered twice: first, with cotton wool, and second, with a filter paper (Whatman No. 1). After that, the filtrates were separately concentrated to dryness using a Rotary Evaporator running at $35-40{ }^{\circ} \mathrm{C}$ and under reduced pressure. The extracts 
obtained from A. hockii (6.71 g), A. coriaria (8.10 g), C. molle (4.05 g), W. ugandensis (6.50 g), and Z. leprieurii $(5.22 \mathrm{~g})$ were stored at $-4{ }^{\circ} \mathrm{C}$ awaiting phytochemical screening, and antimycobacterial activity testing.

For aqueous extractions, the powdered plant part (200 g) of each of the following: A. hockii (stem bark), A. coriaria (stem bark), C. molle (leaves), W. ugandensis (stem bark), and Z. leprieurii (root bark) was soaked in hot distilled water $(1200 \mathrm{~mL})$ at $60{ }^{\circ} \mathrm{C}$ and shaken well. The mixtures were heated in a water bath kept at $60{ }^{\circ} \mathrm{C}$ for $2 \mathrm{~h}$ with frequent shaking. The extracts were subjected to a triple filtration: first, with a cotton piece of cloth, and then second and third, with cotton wool. The filtrates were subjected to freeze-drying, and the extracts obtained from A. hockii (12.84 g), A. coriaria (10.93 g), C. molle (17.50 g), W. ugandensis (15.51 g), and Z. leprieurii $(11.85 \mathrm{~g})$, were stored at $-4{ }^{\circ} \mathrm{C}$ awaiting phytochemical screening, antimycobacterial activity and acute toxicity testing.

\section{Phytochemical screening of extracts}

The methanol/DCM (1:1) and aqueous extracts from each selected plant species were analyzed for alkaloids, saponins, tannins, flavonoids, steroids, cardiac glycosides, resins, anthraquinones, phenolic compounds, phlobatannins, coumarins, and terpenoids. Standard methods for preliminary phytochemical analysis were used with some minor modifications [20,21]. A detailed description of the method has been included in the Additional file 1 .

\section{Antimycobacterial activity \\ M. tuberculosis strains and preparation of inoculum}

Two experimental mycobacterial strains from a WHO proficiency testing panel were used: a fully susceptible laboratory strain $\left(\mathrm{H}_{37} \mathrm{Rv}\right)$ and a known MDR-TB (375) strain. The strains used were obtained from the Mycobacteriology Laboratory (BSL-3) at the College of Health Sciences, Makerere University. This laboratory has been accredited by the College of American Pathologists (CAP) ISO 15189.

The preserved mycobacterial strains were cultured on Middlebrook 7H10 agar before the susceptibility tests $[22,23]$. Cells that were scraped from freshly growing colonies ( 3 weeks old) were introduced into normal saline $(10 \mathrm{~mL})$. A bacterial suspension equivalent to 0.5 McFarland standards $\left(1.5 \times 10^{8} \mathrm{CFU}\right)$ was prepared using a Sensititre Nephelometer by adding more cells or diluting with more normal saline [23, 24].

\section{Preparation of plant extracts}

The dried plant extracts $(1 \mathrm{~g})$ were dissolved separately in DMSO $(10 \mathrm{~mL})$ to give a concentration of $100 \mathrm{mg} / \mathrm{mL}$ and later sterilized using $0.2 \mu \mathrm{m}$ single-use filters before use.

\section{Determination of minimum inhibitory concentration (MIC) and minimum bactericidal concentration (MBC)}

The MIC and $\mathrm{MBC}$ of the crude extracts against both the susceptible $\left(\mathrm{H}_{37} \mathrm{Rv}\right)$ and MDR-TB strains were determined using microplate alamar blue assay (MABA) protocol with minor modifications [25]. A detailed description has been included in the Additional file 1 .

\section{Experimental animals}

Adult female Wistar albino rats (aged 8-10 weeks) were used for the acute toxicity study. Female rats were preferred, since earlier studies have suggested they are generally more sensitive to toxins than male rats [26]. The animals were fed on pellets (standard diet) obtained from Nuvita Animal Feeds (Jinja, Uganda). The animals had access to tap water ad libitum and were kept at standard laboratory conditions of ventilation, regular $12 \mathrm{~h}$ light $/ 12 \mathrm{~h}$ dark cycle, and temperature $\left(20-30{ }^{\circ} \mathrm{C}\right)$ during the experimental period. The animals were acclimatized to standard laboratory conditions (in plastic cages with stainless steel top) for 2 weeks before the experiments.

\section{Acute toxicity assay}

Acute toxicity study was performed in line with the OECD standard guidelines for using animals in scientific research, Guideline No. 425 [27], with minor modifications. Thirty rats were allocated randomly into six groups, each with five rats as follows according to the plant extract administered: Group I (Z. leprieurii-root bark), II (W. ugandensis-stem bark), III (C. molle-leaves), IV (A. coriaria-stem bark), V (A. hockiistem bark) and VI (Control). After a $24 \mathrm{~h}$ starvation (no food provided except water), the single fixed dose of $2000 \mathrm{mg} / \mathrm{kg}$ of the aqueous extract was administered to each rat from Groups I to $\mathrm{V}$ by gavage using an endogastric tube. Rats from Group VI received distilled water $(2 \mathrm{~mL})$ only. The animals were observed regularly and individually for the first $24 \mathrm{~h}$ after dosing for behavioral and general toxicity signs, and particular attention was given during the first $4 \mathrm{~h}$. After that, the animals were given unlimited access to water and food, and observation continued daily for 14 days on clinical signs of toxicity, mortality, and general behavior. Body weights of the animals were measured on days: $0,7,10$, and 14. After the termination of the experiment, three rats from each group were starved overnight and later anesthetized with chloroform. When the anesthesia 
had reached depth, a cardiac puncture was performed on each of the three selected rats per group, and blood samples were collected for biochemical and hematological analyses. Afterward, the animals were euthanized by cervical dislocation, and the following vital organs: heart, kidney, and liver, were removed and processed for histopathological analysis.

\section{Hematological analysis}

Blood samples were stored in EDTA tubes, and hematological analysis was performed using an automated hematology analyzer (SYSMEX XN-L 450 SN 11097). The main parameters evaluated included red blood cells, hemoglobin, mean corpuscular volume, mean corpuscular hemoglobin, mean corpuscular hemoglobin concentration, hematocrit, platelets, white blood cells, lymphocytes, monocytes, and neutrophils.

\section{Biochemical analysis}

Dry tubes containing the collected blood samples were centrifuged at $3000 \mathrm{rpm}$ for $15 \mathrm{~min}$ to obtain the serum. An automated analyzer (COBAS 6000) was used to evaluate the following parameters: aspartate aminotransferase, alanine aminotransferase, total serum protein, bilirubin, alkaline phosphatase, albumin, serum creatinine, and serum urea [28].

\section{Histopathological analysis}

The vital organs collected from the animals were washed with saline solution $0.9 \%(\mathrm{w} / \mathrm{v})$, weighed, and then fixed in $10 \%$ buffered formaldehyde-calcium solution at a ratio of 1:10 (v/v). The organs were trimmed and processed in an automated tissue processor (Leica TP 1020, German) for paraffin embedding. Sections ( $5 \mu \mathrm{m}$ thick) were prepared, adhered onto microscope slides, and stained with hematoxylin and eosin (HE). The tissue sections were examined under a microscope (Nikon Eclipse Phase Contrast, Japan) for their general structure, lesions associated with toxicity such as degenerative changes, necrosis, and evidence of inflammatory response were recorded and described. The images of the various tissue sections and lesions were captured using a microphotographic imaging system (Nikon digital Sight DS-F 11) [29].

\section{Statistical analysis}

The relative weight of organs, biochemical, and hematological data were expressed as mean \pm standard error of the mean (SEM). The data were subjected to One-Way ANOVA followed by Dunnett's comparison test to compare each group with the Control. A $p$ value $<0.05$ was considered statistically significant. The statistical analysis was carried out using SPSS (IBM SPSS Statistics 20).

\section{Results \\ Phytochemical constituents}

The extracts contained alkaloids, saponins, tannins, flavonoids, steroids, resins, terpenoids, cardiac glycosides, phenolic compounds, and coumarins (Table 1).

\section{Antimycobacterial activity}

The MIC and MBC values for both the susceptible $\mathrm{H}_{37} \mathrm{Rv}$ and MDR-TB strains for aqueous and methanol/DCM $(1: 1)$ extracts are shown in Tables 2 and 3, respectively. For aqueous extracts (Table 2), A. hockii (stem bark)

Table 1 Phytochemical constituents of both the aqueous and methanol/DCM (1:1) extracts

\begin{tabular}{|c|c|c|c|c|c|c|c|c|c|c|}
\hline \multirow[t]{3}{*}{ Phytochemical compounds } & \multicolumn{10}{|c|}{ Plant species } \\
\hline & \multicolumn{2}{|c|}{ AH-SB } & \multicolumn{2}{|c|}{$A C-S B$} & \multicolumn{2}{|c|}{ CML } & \multicolumn{2}{|c|}{ WU-SB } & \multicolumn{2}{|c|}{ ZL-RB } \\
\hline & $\mathrm{AE}$ & OE & $\mathrm{AE}$ & OE & $\mathrm{AE}$ & OE & $\mathrm{AE}$ & OE & $\mathrm{AE}$ & $\mathrm{OE}$ \\
\hline Alkaloids & + & + & + & + & + & + & - & + & + & + \\
\hline Saponins & + & + & + & + & - & - & + & + & + & - \\
\hline Tannins & + & + & + & + & + & + & + & + & + & - \\
\hline Flavonoids & + & + & - & - & + & + & - & - & - & - \\
\hline Steroids & - & - & - & + & + & - & + & + & + & + \\
\hline Cardiac glycosides & - & - & - & + & + & + & + & + & + & + \\
\hline Resins & - & - & - & - & + & + & - & + & + & + \\
\hline Anthraquinones & - & - & - & - & - & - & - & - & - & - \\
\hline Phenolic compounds & + & + & + & + & + & + & + & - & + & + \\
\hline Phlobatannins & - & - & - & - & - & - & - & - & - & - \\
\hline Coumarins & - & - & - & + & + & + & + & + & + & + \\
\hline Terpenoids & + & + & + & + & + & + & + & + & + & + \\
\hline
\end{tabular}

AH-SB Acacia hockii stem bark, AC-SB Albizia coriaria stem bark, CM-L Combretum molle leaves, WU-SB Warburgia ugandensis stem bark, ZL-RB Zanthoxylum leprieurii root bark, $A E$ aqueous extract, $O E$ Organic extract [methanol/DCM $(1: 1)] ;(+)=$ present; $(-)=$ absent 
Table 2 Mean MIC and MBC values of aqueous crude extracts of selected plant species on susceptible and MDR strains of M. tuberculosis

\begin{tabular}{|c|c|c|c|c|}
\hline \multirow[t]{2}{*}{ Plant species-part } & \multicolumn{2}{|l|}{ Mean MIC $(\mu \mathrm{g} / \mathrm{mL})$} & \multicolumn{2}{|l|}{ Mean MBC $(\mu \mathrm{g} / \mathrm{mL})$} \\
\hline & $\mathrm{H}_{37} \mathrm{Rv}$ & MDR & $\mathrm{H}_{37} \mathrm{Rv}$ & MDR \\
\hline $\mathrm{AH}-\mathrm{SB}$ & $293.00 \pm 138.60$ & $1172.00 \pm 553.00$ & $391.00 \pm 0.00$ & $781.00 \pm 0.00$ \\
\hline$A C-S B$ & $2344.00 \pm 1105.00$ & $4688.00 \pm 2210.00$ & $1563.00 \pm 0.00$ & $4688.00 \pm 2210.00$ \\
\hline$C M-L$ & $1172.00 \pm 553.00$ & $2344.00 \pm 11.05 .00$ & $1563.00 \pm 0.00$ & $1172.00 \pm 553.00$ \\
\hline WU-SB & $1172.00 \pm 553.00$ & $1563.00 \pm 0.00$ & $2344.00 \pm 1105.00$ & $1563.00 \pm 0.00$ \\
\hline ZL-RB & $781.00 \pm 0.00$ & $1563.00 \pm 0.00$ & $2344.00 \pm 1105.00$ & $2344.00 \pm 1105.00$ \\
\hline
\end{tabular}

AH-SB Acacia hockii stem bark, AC-SB Albizia coriaria stem bark, CM-L Combretum molle leaves, WU-SB Warburgia ugandensis stem bark, ZL-RB Zanthoxylum leprieurii root bark. Values are presented as mean \pm Standard deviation

Table 3 Mean MIC and MBC values of methanol/DCM (1:1) crude extracts of different plant species obtained from different strains of M. tuberculosis

\begin{tabular}{|c|c|c|c|c|}
\hline \multirow[t]{2}{*}{ Plant species-part } & \multicolumn{2}{|c|}{ Mean MIC $(\mu \mathrm{g} / \mathrm{mL})$} & \multicolumn{2}{|c|}{ Mean MBC $(\mu \mathrm{g} / \mathrm{mL})$} \\
\hline & $\mathrm{H}_{37} \mathrm{Rv}$ & MDR & $\mathrm{H}_{37} \mathrm{Rv}$ & MDR \\
\hline $\mathrm{AH}-\mathrm{SB}$ & $98.00 \pm 0.00$ & $293.00 \pm 138.60$ & $391.00 \pm 0.00$ & $781.00 \pm 0.00$ \\
\hline$A C-S B$ & $391.00 \pm 0.00$ & $781.00 \pm 0.00$ & $781.00 \pm 0.00$ & $2344.00 \pm 1105.00$ \\
\hline$C M-L$ & $293.00 \pm 138.60$ & $391.00 \pm 0.00$ & $781.00 \pm 0.00$ & $1563.00 \pm 0.00$ \\
\hline WU-SB & $586.00 \pm 275.80$ & $586.00 \pm 275.80$ & $1563.00 \pm 0.00$ & $2344.00 \pm 1105.00$ \\
\hline ZL-RB & $195.00 \pm 0.00$ & $293.00 \pm 138.6$ & $3125.00 \pm 0.00$ & $2344.00 \pm 1105.00$ \\
\hline
\end{tabular}

AH-SB Acacia hockii stem bark, AC-SB Albizia coriaria stem bark, CM-L Combretum molle leaves, WU-SB Warburgia ugandensis stem bark, ZL-RB Zanthoxylum leprieurii root bark. Values are presented as mean \pm Standard deviation

showed a moderate antimycobacterial activity (MIC, $293 \mu \mathrm{g} / \mathrm{mL}$ ) against the susceptible $\mathrm{H}_{37} \mathrm{Rv}$ strain but a low activity (MIC, $1172 \mu \mathrm{g} / \mathrm{mL}$ ) against the MDR-TB strain. The other species: A. coriaria, C. molle, W. ugandensis, and $Z$. leprieurii (root bark), showed low activities against both the susceptible $\mathrm{H}_{37} \mathrm{Rv}$ and MDR-TB strains.

For the methanol/DCM (1:1) extracts (Table 3), the five plant extracts had significant to moderate activities against the susceptible $\mathrm{H}_{37} \mathrm{Rv}$ and moderate to low activities against the MDR-TB strain. In particular, A. hockii showed a significant antimycobacterial activity (MIC, $98 \mu \mathrm{g} / \mathrm{mL}$ ) against the susceptible $\mathrm{H}_{37} \mathrm{Rv}$ but a moderate activity against the MDR-TB strain (MIC, $293 \mu \mathrm{g} / \mathrm{mL}$ ). Also, Z. leprieurii, C. molle, and W. ugandensis showed moderate activity against the susceptible $\mathrm{H}_{37} \mathrm{Rv}$ and MDR-TB strains. In addition, $A$. coriaria showed moderate activity against the susceptible $\mathrm{H}_{37} \mathrm{Rv}$ strain but a low activity against the MDR-TB strain.

\section{Acute toxicity}

\section{General signs and mortality}

The parameters observed for acute toxicity signs after administering the plant extracts are shown in Table 4 . No significant changes in behavior were observed in the treated groups following the acute toxicity study. However, one death was recorded from the $A$. coriaria (stem bark) treated group on the fourth day during the 14 days of the experiment. In addition, there was lethargy in all the treated groups for up to $4 \mathrm{~h}$ following administration of the extracts. Increased respiration was observed in the A. coriaria and $Z$. leprieurii (root bark) treated groups. There was excessive urination and increased defecation in the A. coriaria (stem bark) treated group for 3 days after administration. Furthermore, there was excessive urination in the $A$. hockii (stem bark) treated group for up to 2 days after administration.

\section{Body and relative organ weights}

Body weights of animals from both the Control and treated groups increased progressively throughout the experimental period, as shown in Fig. 1. The relative organ weights from the Control and treated groups are presented in Table 5. No significant variations were recorded in the relative organ weights of the treated groups when compared to the Control.

\section{Hematological parameters}

The results of the hematological analysis are given in Table 6. There were no remarkable alterations in the levels of RBC, HGB, HCT, MCH, PLT, WBC, LYMPH, MONO, and NEUT from all the treated groups compared with the Control group. Nonetheless, the MCHC 
Table 4 General appearance and behavioral patterns of animals from the treated and Control group

\begin{tabular}{|c|c|c|c|c|c|c|}
\hline \multirow[t]{2}{*}{ Parameters } & \multicolumn{6}{|c|}{ Plant species } \\
\hline & Ctrl & $\mathrm{AH}-\mathrm{SB}$ & AC-SB & CM-L & WU-SB & ZL-RB \\
\hline Mortality & $0 / 5$ & $0 / 5$ & $1 / 5$ & $0 / 5$ & $0 / 5$ & $0 / 5$ \\
\hline Urination (excessive) & $x$ & $\sqrt{ }$ & $\sqrt{ }$ & $x$ & $x$ & $x$ \\
\hline Defecation & N & N & $\uparrow$ & N & N & N \\
\hline Diarrhea & $x$ & $x$ & $x$ & $x$ & $x$ & $x$ \\
\hline Salivation & $x$ & $x$ & $x$ & $x$ & $x$ & $x$ \\
\hline Respiration (within 4 h) & $\mathrm{N}$ & $N$ & $\uparrow$ & $N$ & $\mathrm{~N}$ & $\uparrow$ \\
\hline Sleep & $\mathrm{N}$ & $\mathrm{N}$ & $\mathrm{N}$ & N & $\mathrm{N}$ & $\mathrm{N}$ \\
\hline Itching & $x$ & $x$ & $x$ & $x$ & $x$ & $x$ \\
\hline Convulsions/tremors & $x$ & $x$ & $x$ & $x$ & $x$ & $x$ \\
\hline Lethargy (within 4 h) & $x$ & $\sqrt{ }$ & $\sqrt{ }$ & $\sqrt{ }$ & $\sqrt{ }$ & $\sqrt{ }$ \\
\hline Coma & $x$ & $x$ & $x$ & $x$ & $x$ & $x$ \\
\hline
\end{tabular}

N-normal, x-not observed, $\uparrow$-increased, $\sqrt{ }$-observed

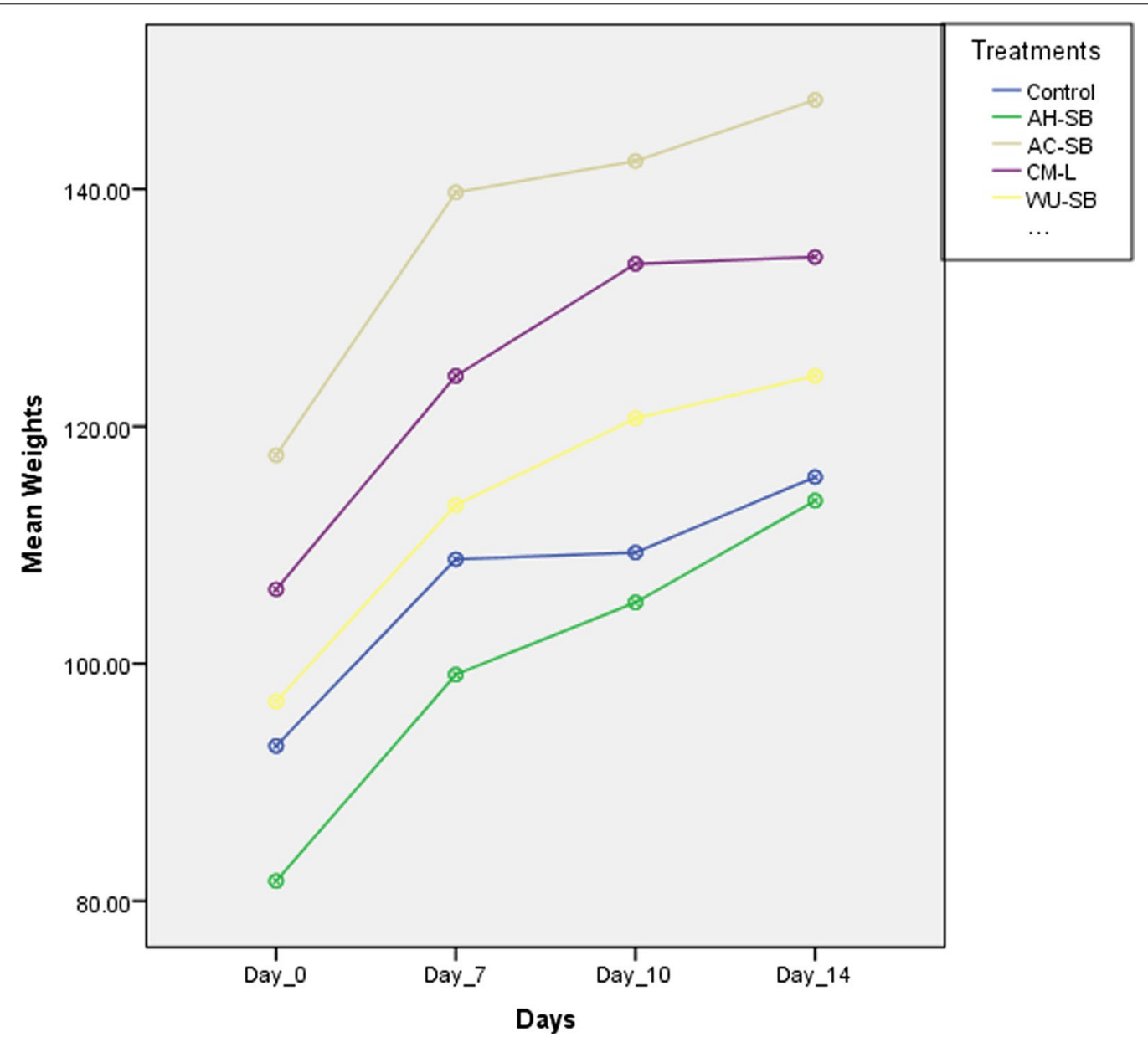

Fig. 1 Showing the variation in mean body weights of animals with time 
Table 5 Effect of extracts of selected plant species on relative weights of organs [(organ weight/body weight) $\times 100 \%$ ] of female rats after 14 days

\begin{tabular}{llllll}
\hline Parameters & \multicolumn{5}{l}{ Plant species } \\
\cline { 2 - 6 } & Control & AH-SB & AC-SB & CM-L & WU-SB \\
\hline Liver & $3.92 \pm 0.06$ & $3.53 \pm 0.37$ & $4.43 \pm 0.22$ & $3.55 \pm 0.31$ & $3.24 \pm 0.13$ \\
L-Kidney & $0.48 \pm 0.03$ & $0.42 \pm 0.04$ & $0.47 \pm 0.06$ & $0.39 \pm 0.04$ & $0.40 \pm 0.03$ \\
Heart & $0.51 \pm 0.03$ & $0.52 \pm 0.04$ & $0.49 \pm 0.00$ & $0.46 \pm 0.03$ & $0.51 \pm 0.06$ \\
Stomach & $1.17 \pm 0.01$ & $1.55 \pm 0.12$ & $1.31 \pm 0.04$ & $1.32 \pm 0.15$ & $1.16 \pm 0.03$ \\
\hline
\end{tabular}

AH-SB Acacia hockii stem bark, AC-SB Albizia coriaria stem bark, CM-L Combretum molle leaves, $W U$-SB Warburgia ugandensis stem bark. Values are presented as mean \pm SEM of triplicates $(n=3)$ level increased significantly $(p<0.001)$ in all the treated groups compared to the Control. In addition, a significant decrease was recorded in the level of MCV $(p<0.05$ and $p<0.001)$ in the $C$. molle and $Z$. leprieurii treated groups, respectively, compared to the Control.

\section{Biochemical parameters}

The results of the various biochemical tests on the Control and treated groups are summarized in Table 7. Treatment with A. hockii, A. coriaria, C. molle, W. ugandensis, and $Z$. leprieurii extracts did not produce statistically significant changes on AST, ALT, ALP, T.P, ALB, and CRE

Table 6 Hematological parameters (Mean \pm SEM) of adult female Wistar albino rats treated with a single dose (2000 mg/kg) of aqueous extracts from selected medicinal plants species after 14 days

\begin{tabular}{|c|c|c|c|c|c|c|}
\hline \multirow[t]{2}{*}{ Parameters } & \multicolumn{6}{|l|}{ Plant species } \\
\hline & Control & AH-SB & AC-SB & CM-L & WU-SB & ZL-RB \\
\hline $\mathrm{RBC}\left(10^{6} / \mu \mathrm{L}\right)$ & $8.40 \pm 0.12$ & $8.54 \pm 0.36$ & $8.32 \pm 0.24$ & $8.64 \pm 0.02$ & $8.44 \pm 0.18$ & $9.06 \pm 0.17$ \\
\hline $\mathrm{HGB}(\mathrm{g} / \mathrm{dL})$ & $14.27 \pm 0.45$ & $14.80 \pm 0.25$ & $14.60 \pm 0.40$ & $15.13 \pm 0.33$ & $15.30 \pm 0.29$ & $14.55 \pm 0.25$ \\
\hline HCT (\%) & $53.10 \pm 1.53$ & $50.73 \pm 1.24$ & $50.53 \pm 1.20$ & $49.77 \pm 0.90$ & $50.93 \pm 0.90$ & $48.45 \pm 0.95$ \\
\hline $\mathrm{MCV}(\mathrm{fL})$ & $63.20 \pm 1.11$ & $59.50 \pm 1.22$ & $60.80 \pm 0.32$ & $57.63 \pm 0.90^{*}$ & $60.37 \pm 1.16$ & $53.45 \pm 0.05^{* * *}$ \\
\hline $\mathrm{MCH}(\mathrm{pg})$ & $16.97 \pm 0.32$ & $17.40 \pm 0.45$ & $17.57 \pm 0.12$ & $17.50 \pm 0.35$ & $18.13 \pm 0.33$ & $16.05 \pm 0.05$ \\
\hline $\mathrm{MCHC}(\mathrm{g} / \mathrm{dL})$ & $26.90 \pm 0.21$ & $29.17 \pm 0.30^{* * *}$ & $28.90 \pm 0.15^{* *}$ & $30.40 \pm 0.21^{* * *}$ & $30.03 \pm 0.09^{* * *}$ & $30.05 \pm 0.05^{* * *}$ \\
\hline $\operatorname{PLT}\left(10^{3} / \mu \mathrm{L}\right)$ & $568.33 \pm 35.20$ & $787.33 \pm 29.00$ & $887.00 \pm 53.50$ & $523.00 \pm 220.37$ & $565.67 \pm 228.46$ & $858.00 \pm 88.00$ \\
\hline WBC $\left(10^{3} / \mu \mathrm{L}\right)$ & $4.59 \pm 1.53$ & $6.30 \pm 0.89$ & $6.36 \pm 1.71$ & $5.16 \pm 1.12$ & $3.16 \pm 1.09$ & $5.26 \pm 2.46$ \\
\hline LYMPH (\%) & $67.43 \pm 1.82$ & $70.20 \pm 3.19$ & $67.13 \pm 6.75$ & $83.50 \pm 3.31$ & $82.70 \pm 1.97$ & $56.75 \pm 4.25$ \\
\hline MONO (\%) & $3.40 \pm 1.16$ & $0.73 \pm 0.15$ & $0.63 \pm 0.03$ & $0.40 \pm 0.15$ & $0.23 \pm 0.12$ & $3.90 \pm 2.10$ \\
\hline NEUT (\%) & $24.03 \pm 1.67$ & $23.90 \pm 2.65$ & $27.33 \pm 7.27$ & $14.83 \pm 3.48$ & $15.60 \pm 1.47$ & $24.40 \pm 6.00$ \\
\hline
\end{tabular}

$R B C$ red blood cells, $H G B$ hemoglobin, $H C T$ hematocrit, $M C V$ mean corpuscular volume, $M C H$ mean corpuscular hemoglobin, $M C H C$ mean corpuscular hemoglobin concentration, PLT platelet, WBC white blood cells, LYMPH lymphocyte count, MONO monocytes, NEUT neutrophils. Values are presented as mean \pm SEM of triplicates $(n=3) .{ }^{*} p<0.05,{ }^{* *} p<0.01,{ }^{* * *} p<0.001$ indicate significant changes in comparison with the control

Table 7 Biochemical parameters of adult female Wistar albino rats treated with a single dose (2000 mg/kg) of aqueous extracts from selected medicinal plant species for 14 days

\begin{tabular}{lcccccc}
\hline Parameters & \multicolumn{1}{l}{ Plant species } & & & & \\
\cline { 2 - 7 } & Control & AH-SB & AC-SB & CM-L & WU-SB & ZL-RB \\
\hline AST $(\mathrm{U} / \mathrm{L})$ & $261.90 \pm 49.97$ & $264.20 \pm 43.02$ & $211.23 \pm 17.84$ & $271.23 \pm 65.38$ & $190.80 \pm 9.62$ & $307.25 \pm 17.55$ \\
ALT $(\mathrm{U} / \mathrm{L})$ & $62.77 \pm 8.20$ & $78.07 \pm 2.92$ & $72.70 \pm 9.40$ & $57.63 \pm 3.79$ & $62.27 \pm 6.68$ & $63.45 \pm 5.75$ \\
ALP $(\mathrm{U} / \mathrm{L})$ & $80.33 \pm 2.03$ & $90.67 \pm 10.35$ & $47.33 \pm 10.68$ & $90.00 \pm 11.93$ & $95.67 \pm 6.49$ & $113.00 \pm 9.00$ \\
TP $(\mathrm{g} / \mathrm{L})$ & $68.97 \pm 2.39$ & $65.73 \pm 2.04$ & $73.13 \pm 1.65$ & $65.40 \pm 0.56$ & $65.27 \pm 2.97$ & $69.80 \pm 0.60$ \\
BILT $(\mu \mathrm{mol} / \mathrm{L})$ & $1.40 \pm 0.21$ & $0.90 \pm 0.12$ & $0.87 \pm 0.38$ & $1.30 \pm 0.26$ & $1.10 \pm 0.12$ & $3.10 \pm 0.40 * *$ \\
ALB $(\mathrm{g} / \mathrm{L})$ & $36.07 \pm 1.32$ & $37.90 \pm 2.23$ & $46.33 \pm 8.49$ & $35.37 \pm 0.67$ & $37.53 \pm 1.31$ & $49.75 \pm 1.75$ \\
CRE $(\mu \mathrm{mol} / \mathrm{L})$ & $57.33 \pm 8.21$ & $39.33 \pm 6.69$ & $45.33 \pm 4.84$ & $43.00 \pm 0.58$ & $46.67 \pm 3.71$ & $47.50 \pm 1.50$ \\
Urea $(\mathrm{mmol} / \mathrm{L})$ & $7.37 \pm 0.32$ & $10.17 \pm 0.52^{*}$ & $8.83 \pm 0.55$ & $8.73 \pm 0.99$ & $8.40 \pm 0.26$ & $9.85 \pm 0.65$ \\
\hline
\end{tabular}

AST aspartate aminotransferase, $A L T$ alanine aminotransferase, $A L P$ alkaline phosphatase, $T P$ total proteins, BILT bilirubin total, $A L B$ albumen, $C R E$ creatinine. Values are presented as mean \pm SEM of triplicates $(n=3) .{ }^{*} p<0.05 ;{ }^{*} p<0.01$ indicate significant changes in comparison with the control 


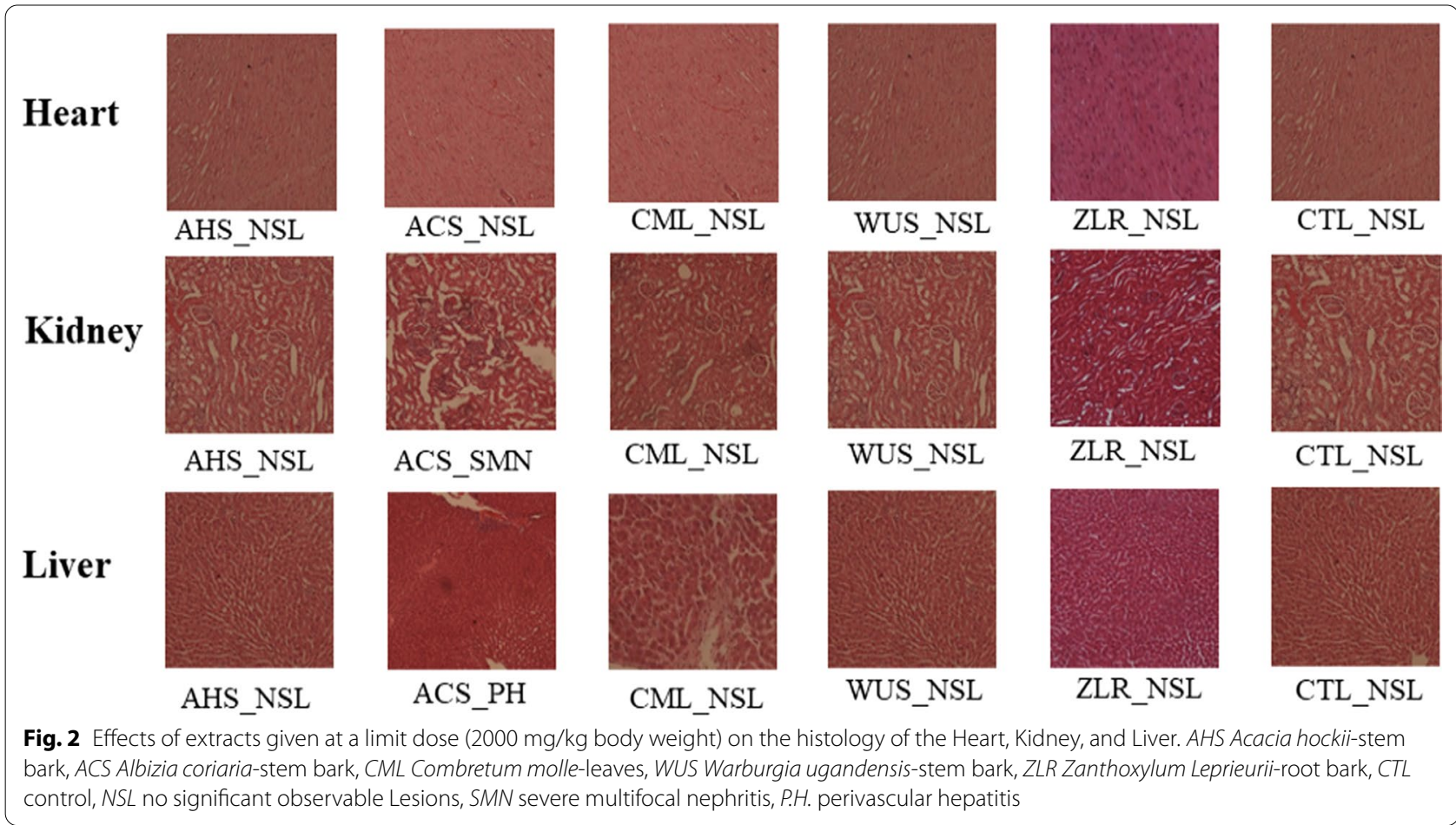

when compared with the Control. However, there was a significant increase in the levels of BILT $(p<0.01)$ and Urea $(p<0.05)$ from the $Z$. leprieurii and A. hockii treated groups, respectively, in comparison to the Control.

\section{Histopathological analysis}

The histopathological report of the following vital organs: kidney, heart, and liver of animals from the Control and treated groups are presented in Fig. 2, and it suggests that there were no visible significant lesions in the Control and $A$. hockii, C. molle, W. ugandensis, and Z. leprieurii treated groups. However, significant changes in the kidney (severe acute multifocal nephritis) and liver (periportal hepatitis) were observed from the $A$. coriaria treated group.

\section{Discussion}

Phytochemical screening results of the selected extracts revealed the presence of many classes of phytochemical compounds, and it is the first report of the presence of the phytochemicals from the aqueous and methanol/ DCM (1:1) extracts of the selected plant species. However, the aqueous and methanol/DCM (1:1) A. hockii stem bark extracts from the present study revealed the same phytochemicals as those detected in the A. hockii stem bark methanol extract [30]. In addition, all the phytochemicals (except saponins) detected from the C. molle leaf extract in the present study are the same as those revealed from the C. molle leaf methanol extract [31].

Studies have reported that many classes of phytochemicals have antimycobacterial activity. For example, alkaloids such as ambiguine $\mathrm{K}$, ambiguine $\mathrm{A}$ isonitrile, ambiguine $\mathrm{C}$ isonitrile, ambiguine $\mathrm{E}$ isonitrile, ambiguine I isonitrile, trans-fagaramide, hapalindole G, hapalindole $\mathrm{H}$, hydroxy-1, 3-dimethoxy-10-methyl-9-acridone, and solsodomine A, isolated from the berries of Solanum sodomaeum, stem bark of Z. leprieurii and the Cyanobacterium Fischerella ambigua, have antimycobacterial activities [7, 8, 32, 33]. Jujubogenin 3-O- $\alpha$-L-arabinofuranosyl $(1 \rightarrow 2)$-[3-O-(trans)- $p$-coumaroyl- $\beta$-D-glucopyranosyl $(1 \rightarrow 3)]-\alpha-\mathrm{L}$-arabinopyranoside, a saponin isolated from Colubrina retusa, also showed antimycobacterial activity [34]. Tannins extracted from C. molle stem bark such as ellagitannin and punicalagin showed activity against $M$. tuberculosis [35]. In addition, the following flavonoids isolated from various plant species exhibited antimycobacterial activity: amentoflavone, dehydrolupinifolinol, demethoxykanugin, 3,7-dimethoxyflavone, eriosemaone A, flemichin, 4-hydroxylonchocarpin, isobachalcone, kanzanol C, karanjachromene, lacheolatin B, lantanoside, linaroside, lupinifolin, lupinifolinol, maackiain, pinnatin and stipulin [36-38]. $\beta$-sitostenone and ergosterol peroxide which are steroids isolated from the twigs and leaves of $R$. boniana showed antitubercular properties [39]. 
Plant terpenoids including longifolene, sesquiterpene, totarol, and trans-communic acid showed activity against M. tuberculosis $\mathrm{H}_{37} \mathrm{Rv}$. Furthermore, totarol and longifolene were active when tested on rifampicin-resistant variants [40]. Therefore, we propose that the antimycobacterial activity exhibited by the selected plant extracts in the present study could be attributed to the main bioactive components, including alkaloids, saponins, tannins, flavonoids, steroids, and terpenoids.

Regarding the isolation of compounds from the selected plant species, no compound has been reported from A. hockii stem bark. Meanwhile, acacic acid lactone, lupeol, lupenone, (+)-catechin, betulinic acid, and benzyl alcohol were reported from the ethyl acetate extract of the stem bark of $A$. coriaria [41]. Regarding the chemistry of $C$. molle, steroidal acid saponins were isolated from its leaves [42]. The following sesquiterpenes: cinnamolide, cinnamolide- $3 \beta$-acetate, linoleic acid, 4(13),7-coloratadien-12,11-olide, $\quad 6 \alpha, \quad 9 \alpha$-dihydroxy4(13),7-coloratadien-11,12-dial, $\quad 7 \beta$-hydroxy-4(13),8coloratadien-11,12-olide, mukaadial, muzigadial, muzigadiolide, $11 \alpha$-hydroxymuzigadiolide, $7 \alpha$-hydroxy8-drimen-11,12-olide, ugandensolide, ugandensidial, and warburganal were isolated from the stem bark of W. ugandensis. In addition, $Z$. leprieurii methanol root extract afforded the following compounds: $10-\mathrm{O}-$ demethyl-12-O-methylarnottianamide, 10-O-demethyl-12-Omethyl isoarnottianamide, and hesperidin [43].

Both the aqueous and methanol/DCM crude extracts of the selected plant species examined in this study exhibited promising in vitro antimycobacterial activities against the susceptible and MDR strains of M. tuberculosis. The activity of the extracts against $M$. tuberculosis was classified based on the following criteria: activity of MIC $(\mu \mathrm{g} / \mathrm{mL})<100$ was considered significant, MIC $(\mu \mathrm{g} /$ $\mathrm{mL}$ ) 100-625 was considered moderate, and weak or low for MIC $(\mu \mathrm{g} / \mathrm{mL})>625[44]$.

In general, the methanol/DCM (1:1) extracts registered a higher antimycobacterial activity than aqueous extracts, which agrees with a previous report by Abuzeid et al. (2014). This finding could be attributed to the ability of the medium polar (methanol/DCM, 1:1) solvent system to extract less-polar and lipophilic bioactive molecules which have higher permeability across the lipid cell membranes of the M. tuberculosis and thus inhibiting its growth, resulting in higher antimycobacterial activity; meanwhile, the aqueous extracts contain polar molecules with reduced permeability across the membranes leading to low antimycobacterial activity [46]. Many studies have reported less-polar antimycobacterial compounds [4749]. In addition, the methanol/DCM solvent system, with a wide solvent polarity range, could have afforded a high chemical diversity of the extracted compounds, resulting in synergism in the crude extract and hence, the higher antimycobacterial activity of the extracts. The findings from this study provide solid evidence that the stem bark of $A$. hockii, which showed significant activity, can be a potential source of antimycobacterial molecules. Therefore, it is a good candidate for further scientific investigations to establish the compounds responsible for the activity. The other plant extracts which have exhibited moderate activity are also worth further investigations as they may have highly bioactive compounds, though few. This is the first report of the antimycobacterial activity of the extracts of $A$. hockii (stem bark), A. coriaria (stem bark), C. molle (leaves), W. ugandensis (stem bark), and $Z$. leprieurii (root bark).

Furthermore, the moderate activity of $A$. hockii aqueous extract against the susceptible $\mathrm{H}_{37} \mathrm{Rv}$ could be important, since many previous reports indicated that aqueous extracts lack bioactivity against $M$. tuberculosis $[47,50]$. Although this study reports a moderate to low/ weak activity exhibited by the aqueous extracts, consuming a significant amount of the extracts could treat tuberculosis. It may help explain the therapeutic effects of the selected plant species as claimed by the local communities.

Further still, since the bactericidal activity is defined by the ratio of $\mathrm{MBC}$ to MIC being less than or equal to 4, methanol/DCM (1:1) extracts of $A$. hockii, A. coriaria, $C$. molle, and W. ugandensis are bactericidal, while that of $Z$. leprieurii is bacteriostatic [51]. This is particularly important because bactericidal anti-TB agents are needed to avoid relapse and lessen the risk of developing resistance in M. tuberculosis [52].

From previous studies, the following ethnobotanical uses apart from antimycobacterial activity have been reported for the plant species in this study. A. hockii has antioxidant and anti-inflammatory activities [53, 54]. The root or stem barks of $A$. coriaria are used as a general tonic and to treat syphilis, cough, skin diseases, eye diseases, jaundice, and sore throat $[14,55]$. It is also used to treat diarrhea, stomach ache, cancer, malaria, antibacterial and antifungal infections, and dermatological diseases [56, 57]. C. molle is used as a remedy for several diseases, including aphrodisiac, malaria, pain, bacterial infections, ulcers, diarrhea, hemorrhoids, syphilis, and also to manage HIV/AIDS-related symptoms [58, 59]. The leaves, root, and stem bark of W. ugandensis are used locally to treat the following conditions: allergies, anemia/blood infections, candidiasis, cough/T.B/ asthma, diarrhea, fallopian tube blockage, fatigue, fever, influenza, hypertension, measles, miscarriage, nasal congestion, nose bleeding, sore throat, stomach ache, syphilis, ulcers, skin rashes and also, to manage HIV/AIDS $[14,59]$. Z. leprieurii is used to treat urinary infections, 
rheumatic pain, and malaria. It is also used as an antiseptic and manages HIV/AIDS-related symptoms [60].

On the other hand, toxicological assessment is crucial for authentication of the safety of herbal medications. There are no previous reports about the acute and subacute toxicity studies of the plants selected in the present study. Therefore, the current study was also conducted to assess the acute toxicity profiles of aqueous extracts of the selected plant species in animal models using the OECD guidelines 425 [27]. This is because an acute toxicity study is needed to establish a safer dose range to manage the clinical signs and symptoms of the drugs [61]. Consequently, according to Namulindwa et al. (2015), the excessive urination recorded from the $A$. coriaria and $A$. hockii treated groups in this study could be linked to toxicity. Furthermore, no significant changes were detected in body weight gains of animals in the treated groups during the study, and this suggests that the normal processing of all the nutrients such as carbohydrates, fats, and proteins have been metabolized appropriately within the body as these nutrients play a significant role in physiological functions [63].

Vital organs, including the liver, heart, kidney, spleen, and lungs, are functionally crucial organs often impaired by toxic substances [64]. In this study, the Control, and treated groups, A. hockii, C. molle, W. ugandensis, and Z. leprieurii showed no visible significant lesions upon histological examinations and, therefore, may not be acutely toxic to the vital organs. However, the $A$. coriaria treated group's findings showed clear evidence of organ toxicity, where severe multifocal nephritis and perivascular hepatitis, more pronounced in the portal area, were observed in the kidney and liver, respectively. The severe multifocal nephritis observed in this study is most likely linked to an $A$. coriaria extract-induced nephritis characterized by inflammatory cells infiltration at various locations in the renal interstitium. Furthermore, perivascular hepatitis in the liver could be linked to an $A$. coriaria aqueous extract induced hepatocellular injury leading to the observed inflammatory cells (mainly neutrophils and lymphocytes) aggregated around the blood vessels, particularly in the hepatic portal area. These findings corroborate well with the clinical signs of toxicity, such as increased respiration, excessive urination, and defecation, and the single mortality registered upon oral administration of $A$. coriaria extract. These findings also agree with many studies which have reported toxic extracts/compounds from the Genus Albizia [65-68]. This indicates that A. coriaria is moderately toxic at the current dose of $2000 \mathrm{mg} / \mathrm{kg}$.

Hematological parameters are sensitive biomarkers of the physiological changes in reaction to any toxic substances [69]. In this study, there was a significant decrease in the level of MCV from the C. molle and $Z$. leprieurii treated groups. Since MCV measures the average size or volume of $\mathrm{RBC}$, a low MCV (microcytic) observed in the $C$. molle and $Z$. leprieurii treated groups is consistent with anemia [70-72]. From the results obtained, it may be argued that aqueous extracts of $C$. molle (leaves) and $Z$. leprieurii (root bark) may cause anemia.

Numerous toxic compounds accumulate in the liver, where they are detoxified [73]. Liver damage is typically assessed by determining serum transaminases (AST and ALT) and measuring total proteins. Liver injury caused by hepatotoxic drugs can result in elevated AST, ALT, and total protein levels [74, 75]. Hepatocellular damage could increase cell membrane permeability and then lead to the release of aminotransferases into the bloodstream $[76,77]$. Since no significant alterations were detected in serum levels of these three markers of liver function, and histopathological analyses of the livers from treated animals did not show tissue changes, the findings from the present study suggest that administration of the extracts from the selected plant species did not cause liver damage.

The kidneys receive about $25 \%$ of the cardiac blood flow, and any substance that reaches the systemic circulation will reach this organ; hence, they are considered frequent toxicity targets [78]. Renal function is usually assessed by serum creatinine and urea levels and histopathological analysis of the kidney tissues. Its impairment is shown by raised serum creatinine levels and urea [79]. Urea is a marker of acute renal dysfunction, the first acute marker following renal injury [80]. In this study, a significant increase in the level of urea was observed in the $A$. hockii treated group, suggesting a mild renal injury. This finding is also supported by the excessive urination observed from the same group.

According to the OECD guidelines No 425 [27], the LD 50 of a substance is considered to be greater than $2000 \mathrm{mg} / \mathrm{kg}$ if three or more experimental rats in a group of five survive after administering a limit dose of $2000 \mathrm{mg} / \mathrm{kg}$ body weight. In this study, mortality was registered from the $A$. coriaria treated group only, where one rat died. This places the LD 50 of all the groups at greater than $2000 \mathrm{mg} / \mathrm{kg}$. Therefore, since chemicals are divided into five groups based on their LD50 according to the globally harmonized classification system [81], all the extracts considered in this study can be classified into group 5 (LD50>2000 mg/ $\mathrm{kg}$ ), which is the class of least toxicity. In spite of this general classification, signs of toxicity were detected in the organs from the A. coriaria treated group and could be considered somewhat toxic. This is the first report of acute toxicity study of all the selected plant species to the best of our knowledge. 


\section{Conclusions}

Phytochemical screening of the extracts revealed the presence of alkaloids, tannins, saponins, flavonoids, steroids, terpenoids, resins, cardiac glycosides, phenolic compounds, and coumarins. The selected medicinal plants have promising antimycobacterial activity, and low toxicity, except $A$. coriaria, which appears to be moderately toxic. The findings of this study justify the ethnopharmacological use of the plant parts of the selected plant species to treat tuberculosis and other diseases whose symptoms closely resemble tuberculosis. Chronic toxicity studies of the selected plant species will be necessary to support their use further. Furthermore, all the selected plant species in this study are potential candidates for isolation and characterization to identify antimycobacterial compounds responsible for their activities.

\section{Abbreviations}

AIDS: Acquired immunodeficiency syndrome; ANOVA: Analysis of variance; DMSO: Dimethyl sulfoxide; HIV: Human immunodeficiency virus; LD: Lethal dose.

\section{Supplementary Information}

The online version contains supplementary material available at https://doi. org/10.1186/s41182-022-00406-7.

Additional file 1: The detailed descriptions of the standard methods for preliminary phytochemical analysis, the microplate Alamar blue assay (MABA) protocol, and Figure S1 showing the observed efficacy of the extracts using the susceptible Mycobacterium tuberculosis strain $\left(\mathrm{H}_{37} \mathrm{Rv}\right)$.

\section{Acknowledgements}

We gratefully acknowledge Mr. Komakech Kevin from the Mycobacteriology Laboratory at the Department of Microbiology, College of Health Sciences, Makerere University, Uganda, for carrying out the antimycobacterial assay and Mr. Mukwaya Joel from the department of Veterinary Pharmacy, Clinical and Complementary Medicine, College of Veterinary, Animal Resources and Biosecurity, Makerere University, Uganda for his technical guidance during the acute toxicity tests. In addition, we thank Dr. Morgan Andama from the Department of Biology, Faculty of Science, Muni University, for his technical support while running the statistical tests.

\section{Authors' contributions}

BO, JN and RB conceptualized the study. BO collected the plant samples, conducted phytochemical screening, participated in acute toxicity tests and analysis of the data, under the supervision of RB and JN. WS supervised the antimycobacterial activity tests. MA supervised the acute toxicity tests and performed the histopathological examination of the vital organs. $\mathrm{BO}$ drafted the manuscript and RB, JN, WS, and MA critically reviewed it. RB was the overall supervisor of the project. All authors read and approved the final manuscript.

\section{Funding}

This work was supported by the Deutscher Akademischer Austauschdienst (DAAD) In-Country Scholarship, Uganda 2016 (through a DAAD PhD Scholarship to Benson Oloya, Grant no. 91560246). The authors gratefully acknowledge the DAAD for the support.

\section{Availability of data and materials}

All data generated or analyzed during this study are included in this published article.

\section{Declarations}

Ethics approval and consent to participate

This study was conducted with approval from Gulu University Research Ethics Committee (Application No. GUREC-058-19) and Uganda National Council for Science and Technology (No. NS112ES).

\section{Consent for publication}

Not applicable.

\section{Competing interests}

The authors declare that they have no competing interests.

\section{Author details}

${ }^{1}$ Department of Chemistry, College of Natural Sciences, Makerere University, P.O. Box 7062, Kampala, Uganda. ${ }^{2}$ Department of Chemistry, Faculty of Science, Muni University, P.O. Box 725, Arua, Uganda. ${ }^{3}$ Department of Medical Microbiology, College of Health Science, Makerere University, P.O. Box 7072, Kampala, Uganda. ${ }^{4}$ Department of Pharmacy, Clinical and Comparative Veterinary Medicine, College of Veterinary Medicine, Animal Resources and Biosecurity, Makerere University, P.O. Box 7072, Kampala, Uganda.

Received: 13 December 2021 Accepted: 3 February 2022

Published online: 17 February 2022

\section{References}

1. WHO. Global Tuberculosis Report. Geneva; 2020

2. Ebong PE, Atangwho IJ, Eyong EU, Egbung GE. The antidiabetic efficacy of combined extracts from two continental plants: Azadirachta indica (A Juss) (Neem) and Vernonia amygdalina (Del.) (African Bitter Leaf). Am J Biochem Biotechnol. 2008;4:239-44. https://doi.org/10.3844/ajbbsp.2008. 239244

3. Ahmad I, Aqil F, Owais M, editors. Modern phytomedicine: turning medicinal plants into drugs. (Chapter 3) [herbal medicine: prospect and contraints]. WILEY-VCH Verlag GmbH \& Co. KGaA, Weinheim; 2006.

4. Bello IA, Ndukwe GI, Audu OT, Habila JD. A bioactive flavonoid from Pavetta crassipes K. Schum Org Med Chem Lett. 2011;1:1-5. https://doi. org/10.1186/2191-2858-1-14.

5. Sathiya M, Muthuchelian K. Phytochemical investigation and antibacterial screening of ethanolic leaf extract of Sapindus emarginatus Vahl. Ethnobot Leafl. 2008;12:859-95.

6. Lewis K. Platforms for antibiotic discovery. Nat Rev Drug Discov. 2013;12:371-87. https://doi.org/10.1038/nrd3975.

7. Oloya B, Namukobe J, Heydenreich M, Ssengooba W, Schmidt B, Byamukama R. Antimycobacterial activity of the extract and isolated compounds from the stem bark of Zanthoxylum leprieurii Guill. and Perr. Nat Prod Commun. 2021;16:1-8. https://doi.org/10.1177/1934578X2110358 51.

8. Bunalema L, Fotso GW, Waako P, Tabuti J, Yeboah SO. Potential of Zanthoxylum leprieurii as a source of active compounds against drug resistant Mycobacterium tuberculosis. BMC Complement Altern Med. 2017;17:1-6. https://doi.org/10.1186/s12906-017-1602-x.

9. Bunalema L, Kirimuhuzya C, Tabuti JRS, Waako P, Magadula JJ, Otieno $\mathrm{N}$, et al. The efficacy of the crude root bark extracts of Erythrina abyssinica on rifampicin resistant Mycobacterium tuberculosis. Afr Health Sci. 2012:11:587-93.

10. Bunalema L, Tabuti J, Sekagya Y, Ogwang S, Waako P. Anti-tubercular activity of Callistemon citrinus and Piptadenistrum africanum on resistant strains of Mycobacterium tuberculosis using Microplate alamar blue assay. Spat DD Peer Rev J Complement Med Drug Discov. 2015;5:235. https:// doi.org/10.5455/spatula.20160316042034.

11. Tabuti JRS, Kukunda CB, Waako PJ. Medicinal plants used by traditional medicine practitioners in the treatment of tuberculosis and related 
ailments in Uganda. J Ethnopharmacol. 2010;127:130-6. https://doi.org/ 10.1016/j.jep.2009.09.035.

12. Bunalema L, Obakiro S, Tabuti JR, Waako P. Knowledge on plants used traditionally in the treatment of tuberculosis in Uganda. J Ethnopharmacol. 2014;151:999-1004. https://doi.org/10.1016/j.jep.2013.12.020.

13. Muthee JK, Gakuya DW, Mbaria JM, Kareru PG, Mulei CM, Njonge FK. Ethnobotanical study of anthelmintic and other medicinal plants traditionally used in Loitoktok district of Kenya. J Ethnopharmacol. 2011;135:15-21. https://doi.org/10.1016/j.jep.2011.02.005.

14. Anywar G, Kakudidi E, Byamukama R, Mukonzo J, Schubert A, Oryemoriga $\mathrm{H}$. Indigenous traditional knowledge of medicinal plants used by herbalists in treating opportunistic infections among people living with HIV / AIDS in Uganda. J Ethnopharmacol. 2019;2020(246):1-13. https:// doi.org/10.1016/j.jep.2019.112205.

15. Oryema C, Rutaro K, Oyet SW, Malinga GM. Ethnobotanical plants used in the management of symptoms of tuberculosis in rural Uganda. Trop Med Health. 2021;49:1-10. https://doi.org/10.1186/s41182-021-00384-2.

16. Pittler $\mathrm{MH}$, Ernst E. Systematic review: hepatotoxic events associated with herbal medicinal products. Aliment Pharmacol Ther. 2003;18:45171. https://doi.org/10.1046/j.1365-2036.2003.01689.x.

17. Syahmi ARM, Vijayarathna S, Sasidharan S, Latha LY, Kwan YP, Lau YL, et al. Acute oral toxicity and brine shrimp lethality of Elaeis quineensis Jacq., (Oil Palm Leaf) methanol extract. Molecules. 2010;15:8111-21. https://doi.org/10.3390/molecules15118111.

18. Kandhare AD, Bodhankar SL, Mohan V, Thakurdesai PA. Acute and repeated doses (28 days) oral toxicity study of glycosides based standardized fenugreek seed extract in laboratory mice. Regul Toxicol Pharmacol. 2015;72:323-34. https://doi.org/10.1016/j.yrtph.2015.05. 003.

19. Anywar G, Kakudidi E, Byamukama R, Mukonzo J, Schubert A, OryemOriga $\mathrm{H}$, et al. A review of the toxicity and phytochemistry of medicinal plant species used by herbalists in treating people living with HIV/AIDS in Uganda. Front Pharmacol. 2021;12:435. https://doi.org/10.3389/ fphar.2021.615147.

20. Shaikh JR, Patil M. Qualitative tests for preliminary phytochemical screening: an overview. Int J Chem Stud. 2020;8:603-8. https://doi.org/ 10.22271/chemi.2020.v8.i2i.8834

21. Singh V, Kumar R. Study of phytochemical analysis and antioxidant activity of Allium sativum of bundelkhand region. Int J Life-Sciences Sci Res. 2017;3:1451-8. https://doi.org/10.21276/ijlssr.2017.3.6.4.

22. Mohamad S, Zin NM, Wahab HA, Ibrahim P, Sulaiman SF, Zaharilud$\operatorname{din}$ ASM, et al. Antituberculosis potential of some ethnobotanically selected Malaysian plants. J Ethnopharmacol. 2011;133:1021-6. https:// doi.org/10.1016/j.jep.2010.11.037

23. Sanders CA, Nieda RR, Desmond EP. Validation of the use of middlebrook 7H10 Agar, BACTEC MGIT 960, and BACTEC $46012 \mathrm{~B}$ media for testing the susceptibility of Mycobacterium tuberculosis to levofloxacin. J Clin Microbiol. 2004;42:5225-8. https://doi.org/10.1128/JCM.42.11. 5225-5228.2004.

24. Komakech K, Kateregga J, Namaganda C, Semugenze D, Aloysius L. In vitro anti-tuberculosis activity of total crude extract of Echinops amplexicaulis against multi-drug resistant Mycobacterium tuberculosis. J Heal Sci. 2018;6:296-303. https://doi.org/10.17265/2328-7136/2018.04. 008.

25. Lawal TO, Adeniyi BA, Wan B, Franzblau SG, Mahady GB. In-vitro susceptibility of Mycobacterium tuberculosis to extracts of Uvaria afzelli Scott Elliot and Tetracera Alnifolia Willd. African J Biomed Res. 2011;14:17-21.

26. Lipnick RL, Cotruvo JA, Hill RN, Bruce RD, Stitzel KA, Walker AP, et al. Comparison of the up-and-down, conventional LD50, and fixed-dose acute toxicity procedures. Food Chem Toxicol. 1995;33:223-31. https:// doi.org/10.1016/0278-6915(94)00136-C.

27. OECD. Guidelines for the Testing of Chemiclas. Test No. 425, Acute Oral Toxicity: Up-and-Down Procedure. Adopted on 3rd October 2008. 2008

28. Alelign T, Chalchisa D, Fekadu N, Solomon D, Sisay T, Debella A, et al. Evaluation of acute and sub-acute toxicity of selected traditional antiurolithiatic medicinal plant extracts in Wistar albino rats. Toxicol Rep. 2020;7:1356-65. https://doi.org/10.1016/j.toxrep.2020.10.001.

29. Di Fiore SHM. Atlas of human histology. 2nd ed. Philadelphia: Lea \& Febiger; 1963
30. Guchu BM, Machocho AK, Mwihia SK, Ngugi MP. In vitro antioxidant activities of methanolic extracts of Caesalpinia volkensii Harms., Vernonia lasiopus O. Hoffm., and Acacia hockii De Wild. Evid-Based Complement Altern Med. 2020;2020:1-10. https://doi.org/10.1155/2020/3586268.

31. Fankam AG, Kuiate JR, Kuete V. Antibacterial and antibiotic resistance modifying activity of the extracts from Allanblackia gabonensis, Combretum molle and Gladiolus quartinianus against Gram-negative bacteria including multi-drug resistant phenotypes. BMC Complement Altern Med. 2015:15:1-12. https://doi.org/10.1186/s12906-015-0726-0.

32. Mo S, Krunic A, Chlipala G, Orjala J. Antimicrobial ambiguine isonitriles from the cyanobacterium Fischerella ambigua. J Nat Prod. 2009;72:894-9. https://doi.org/10.1021/np800751j.

33. El Sayed KA, Hamann MT, Abd El-Rahman HA, Zaghloul AM. New pyrrole alkaloids from Solanum sodomaeum. J Nat Prod. 1998;61:848-50. https:// doi.org/10.1021/np980042p.

34. ElSohly HN, Danner S, Li X-C, Nimrod AC, Clark AM. New antimycobacterial saponin from Colubrina retusa. J Nat Prod. 1999;62:1341-2. https://doi. org/10.1021/np9901940.

35. Asres K, Bucar F, Edelsbrunner S, Kartnig T, Höger G, Thiel W. Investigations on antimycobacterial activity of some Ethiopian medicinal plants. Phyther Res. 2001;15:323-6. https://doi.org/10.1002/ptr.724.

36. Begum S, Wahab A, Siddiqui BS. Antimycobacterial activity of flavonoids from Lantana camara Linn. Nat Prod Res. 2008;22:467-70. https://doi.org/ 10.1080/14786410600898714

37. Sutthivaiyakit S, Thongnak O, Lhinhatrakool T, Yodchun O, Srimark R, Dowtaisong $\mathrm{P}$, et al. Cytotoxic and antimycobacterial prenylated flavonoids from the roots of Eriosema chinense. J Nat Prod. 2009:72:1092-6. https://doi.org/10.1021/np900021h.

38. Koysomboon S, van Altena I, Kato S, Chantrapromma K. Antimycobacterial flavonoids from Derris indica. Phytochemistry. 2006;67:1034-40. https://doi.org/10.1016/j.phytochem.2006.03.019.

39. Truong NB, Pham CV, Doan HTM, Nguyen HV, Nguyen CM, Nguyen HT, et al. Antituberculosis cycloartane triterpenoids from Radermachera boniana. J Nat Prod. 2011;74:1318-22. https://doi.org/10.1021/np200022b.

40. Gordien AY, Gray Al, Franzblau SG, Seidel V. Antimycobacterial terpenoids from Juniperus communis L. (Cuppressaceae). J Ethnopharmacol. 2009;126:500-5. https://doi.org/10.1016/j.jep.2009.09.007.

41. Byamukama R, Barbara G, Namukobe J, Heydenreich M, Kiremire B. Bioactive compounds in the stem bark of Albizia coriaria (Welw. ex Oliver). Int J Biol Chem Sci. 2015:9:1013. https://doi.org/10.4314/ijbcs.v9i2.37.

42. Pegel $\mathrm{KH}$, Rogers $\mathrm{CB}$. The characterisation of mollic acid $3 \beta-D$ xyloside and its genuine aglycone mollic acid, two novel la-hydroxycycloartenoids from Combretum molle. J Chem Soc Perkin Trans. 1985;1:1711-5.

43. Ngoumfo RM, Jouda JB, Mouafo FT, Komguem J, Mbazoa CD, Shiao TC, et al. In vitro cytotoxic activity of isolated acridones alkaloids from Zanthoxylum leprieurii Guill. et Perr. Bioorganic Med Chem. 2010;18:3601-5. https://doi.org/10.1016/j.bmc.2010.03.040.

44. Kuete V. Potential of cameroonian plants and derived products against microbial infections: a review. Planta Med. 2010;76:1479-91. https://doi. org/10.1055/s-0030-1250027.

45. Abuzeid N, Kalsum S, Koshy RJ, Larsson M, Glader M, Andersson H, et al. Antimycobacterial activity of selected medicinal plants traditionally used in Sudan to treat infectious diseases. J Ethnopharmacol. 2014;157:134-9. https://doi.org/10.1016/.j.jep.2014.09.020.

46. Korycka-Machała M, Rumijowska-Galewicz A, Dziadek J. The effect of ethambutol on mycobacterial cell wall permeability to hydrophobic compounds. Polish J Microbiol. 2005:54:5-11.

47. Jimenez-Arellanes A, Meckes M, Ramirez R, Torres J, Luna-Herrera J, Herrera JL. Activity against multidrug-resistant Mycobacterium tuberculosis in Mexican plants used to treat respiratory diseases. Phytother Res. 2003:17:903-8.

48. Luo X, Pires D, Aínsa JA, Gracia B, Duarte N, Mulhovo S, et al. Zanthoxylum capense constituents with antimycobacterial activity against Mycobacterium tuberculosis in vitro and ex vivo within human macrophages. J Ethnopharmacol. 2013;146:417-22. https://doi.org/10.1016/j.jep.2013.01. 013.

49. Green E, Samie A, Obi CL, Bessong PO, Ndip RN. Inhibitory properties of selected South African medicinal plants against Mycobacterium tuberculosis. J Ethnopharmacol. 2010;130:151-7. https://doi.org/10.1016/j.jep.2010. 04.033. 
50. Camacho-Corona MR, Ramírez-Cabrera MA, González-Santiago O, Garza-González E, Palacios IP, Luna-Herrera J. Activity against drug resistant-tuberculosis strains of plants used in Mexican traditional medicine to treat tuberculosis and other respiratory diseases. Phyther Res. 2008;22:82-5.

51. Peterson LR, Shanholtzer CJ. Tests for bactericidal effects of antimicrobial agents: technical performance and clinical relevance. Clin Microbiol Rev. 1992;5:420-32. https://doi.org/10.1128/CMR.5.4.420.

52. Mohamad S, Ismail NN, Parumasivam T, Ibrahim P, Osman H, Wahab HA. Antituberculosis activity, phytochemical identification of Costus speciosus (J. Koenig) Sm, Cymbopogon citratus (DC. Ex Nees) Stapf, and Tabernaemontana coronaria (L.) Willd and their effects on the growth kinetics and cellular int. BMC Complement Altern Med. 2018;18:1-14. https://doi.org/ 10.1186/s12906-017-2077-5.

53. Kabasa JD, Opuda-Asibo J, Thinggaard G, ter Meulen U. The mineral scoring technique and evaluation of indigenous browse species as natural mineral phytocentres for goats in African Rangelands. Trop Anim Health Prod. 2004;36:365-80. https://doi.org/10.1023/B:TROP.0000026666.86914. $5 \mathrm{~d}$

54. Kamau JK, Nthiga PM, Mwonjoria JK, Ngeranwa JJN, Ngugi MP. Antiinflammatory activity of methanolic leaf extract of Kigelia Africana (Lam.) benth and stem bark extract of Acacia Hockii De Wild in Mice. J Dev Drugs. 2016;5:1-8. https://doi.org/10.4172/2329-6631.1000156.

55. Namukobe J, Kasenene JM, Kiremire BT, Byamukama R, KamatenesiMugisha M, Krief S, et al. Traditional plants used for medicinal purposes by local communities around the Northern sector of Kibale National Park, Uganda. J Ethnopharmacol. 2011;136:236-45. https://doi.org/10.1016/j. jep.2011.04.044.

56. Ochwang'i DO, Kimwele CN, Oduma JA, Gathumbi PK, Mbaria JM, Kiama SG. Medicinal plants used in treatment and management of cancer in Kakamega County, Kenya. J Ethnopharmacol. 2014;151:1040-55.

57. Mugisha MK, Asiimwe S, Namutebi A, Borg-Karlson AK, Kakudidi EK. Ethnobotanical study of indigenous knowledge on medicinal and nutritious plants used to manage opportunistic infections associated with HIV/AIDS in western Uganda. J Ethnopharmacol. 2014;155:194-202. https://doi. org/10.1016/j.jep.2014.05.012.

58. Grønhaug TE, Glæserud S, Skogsrud M, Ballo N, Bah S, Diallo D, et al. Ethnopharmacological survey of six medicinal plants from Mali. WestAfrica J Ethnobiol Ethnomed. 2008;4:1-11. https://doi.org/10.1186/ 1746-4269-4-26.

59. Schultz F, Anywar G, Wack B, Quave CL, Garbe L. Ethnobotanical study of selected medicinal plants traditionally used in the rural Greater Mpigi region of Uganda. J Ethnopharmacol. 2020;256:1-18. https://doi.org/10. 1016/j.jep.2020.112742.

60. Lamorde M, Tabuti JRS, Obua C, Kukunda-Byobona C, Lanyero H, ByakikaKibwika P, et al. Medicinal plants used by traditional medicine practitioners for the treatment of HIV/AIDS and related conditions in Uganda. J Ethnopharmacol. 2010;130:43-53. https://doi.org/10.1016/j.jep.2010.04. 004.

61. Saleem U, Amin S, Ahmad B, Azeem H, Anwar F, Mary S. Acute oral toxicity evaluation of aqueous ethanolic extract of Saccharum munja Roxb. roots in albino mice as per OECD 425 TG. Toxicol Rep. 2017;4:580-5. https://doi. org/10.1016/j.toxrep.2017.10.005.

62. Namulindwa A, Nkwangu D, Oloro J. Determination of the abortifacient activity of the aqueous extract of Phytolacca dodecandra (L'Her) leaf in Wistar rats. Acad J. 2015;9:43-7. https://doi.org/10.5897/AJPP2014.

63. Stevens KR, Mylecraine L. Issues in chronic toxicology. Princ Methods Toxicol. 1994;3:673

64. Auletta C. Acute, Subchronic, and Chronic Toxicology. In: Handbook of Toxicology, Second Edition. London: Informa Healthcare; 2001. https:// doi.org/10.1201/9781420042078.ch2.

65. He Y, Wang Q, Ye Y, Liu Z, Sun H. The ethnopharmacology, phytochemistry, pharmacology and toxicology of genus Albizia: a review. J Ethnopharmacol. 2020;257:1-66. https://doi.org/10.1016/j.jep.2020.112677.

66. Lipton A. Abortifacient and toxic actions of the glycoside 'albitocin' extracted from some Albizia species. J Pharm Pharmacol. 2011;19:792-6. https://doi.org/10.1111/j.2042-7158.1967.tb09545.x.

67. Razanatseheno AJ, Randriamampianina LJ, Randrianarivo HR, Rakoto DAD, Jeannoda VL. Evaluation of the toxic effects of Albizia mahalao Capuron extracts, a Fabaceae from Madagascar, on different organisms.
GSC Biol Pharm Sci. 2020;11:287-96. https://doi.org/10.30574/gscbps. 2020.11.2.0144

68. Noté OP, Mitaine-Offer A-C, Miyamoto T, Paululat T, Mirjolet J-F, Duchamp $\mathrm{O}$, et al. Cytotoxic acacic acid glycosides from the roots of Albizia coriaria. Nat Prod. 2009;72:1725-30. https://doi.org/10.1021/np900126r.

69. Jain N, Sharma P, Sharma N, Joshi SC. Haemato-biochemical profile following sub-acute toxicity of malathion in male albino rats. Pharmacologyonline. 2009;2:500-6.

70. Arika WM, Nyamai DW, Musila MN, Ngugi MP, Njagi ENM. Hematological markers of in vivo toxicity. J Hematol Thromboembolic Dis. 2016;4:1-7. https://doi.org/10.4172/2329-8790.1000236.

71. Hall JE. Red blood cells, anemia and polycythemia. In: Guyton and Hall Textbook of Medical Physiology. 13th edition. Saunders, USA; 2016. p. 445-54.

72. Leach M. Interpretation of the full blood count in systemic disease-a guide for the physician. J R Coll Physicians Edinb. 2014;44:36-41. https:// doi.org/10.4997/JRCPE.2014.109.

73. Clarke EGC, Clarke ML. Veterinary Toxicology. London; 1977.

74. Ramaiah SK. Preclinical safety assessment: current gaps, challenges, and approaches in identifying translatable biomarkers of drug-induced liver injury. Clin Lab Med. 2011;31:161-72. https://doi.org/10.1016/j.cll.2010.10. 004.

75. Ozer J, Ratner M, Shaw M, Bailey W, Schomaker S. The current state of serum biomarkers of hepatotoxicity. Toxicology. 2008;245:194-205. https://doi.org/10.1016/j.tox.2007.11.021.

76. Ogunlana OO, Ogunlana OE, Adeneye AA, Udo-Chijioke OAC, DareOlipede TI, Olagunju JA, et al. Evaluation of the toxicological profile of the leaves and young twigs of Caesalpinia bonduc (linn) roxb. African J Tradit Complement Altern Med. 2013;10:504. https://doi.org/10.4314/ajtcam. v10i6.20.

77. Friedman LS, Martin P, Munoz SJ. Liver function tests and the objective evaluation of the patient with liver disease. In: Zakin D, Boyer TD, editors. Hepatology: a textbook of liver disease. 3rd ed. Philadelphia: WB Saunders; 1996. p. 791-833.

78. Dekant W, Vamvakas S. Biotransformation and membrane transport in nephrotoxicity. Crit Rev Toxicol. 1996;26:309-34. https://doi.org/10.3109/ 10408449609012526.

79. Travlos GS, Morris RW, Elwell MR, Duke A, Rosenblum S, Thompson MB. Frequency and relationships of clinical chemistry and liver and kidney histopathology findings in 13-week toxicity studies in rats. Toxicology. 1996;107:17-29. https://doi.org/10.1016/0300-483X(95)03197-N.

80. Olayode OA, Daniyan MO, Gbola O. Biochemical, hematological and histopathological evaluation of the toxicity potential of the leaf extract of Stachytarpheta cayennensis in rats. J Tradit Complement Med. 2020;10:544-54. https://doi.org/10.1016/j.jtcme.2019.05.001.

81. Secretariat, United Nations EC for E. Globally Harmonized System of Classification and Labelling of Chemicals (ghs). United Nations Publ 2009. 2017.

\section{Publisher's Note}

Springer Nature remains neutral with regard to jurisdictional claims in published maps and institutional affiliations.

Ready to submit your research? Choose BMC and benefit from

- fast, convenient online submission

- thorough peer review by experienced researchers in your field

- rapid publication on acceptance

- support for research data, including large and complex data types

- gold Open Access which fosters wider collaboration and increased citations

- maximum visibility for your research: over 100M website views per year

At BMC, research is always in progress.

Learn more biomedcentral.com/submissions 